\title{
Characterization of Potential Probiotics Bacillus subtilis CS90 from Soybean Paste (Doenjang) and Its Antimicrobial Activity against Food-borne Pathogens
}

\author{
Kye Man Cho* \\ Research Institute of Agricultural Science and Department of Agricultural Chemistry, \\ Sunchon National University, Suncheon 540-742, Republic of Korea
}

Received September 20, 2008; Accepted November 14, 2008

\begin{abstract}
A potential probiotics bacterial strain, CS90, was isolated from Korean soybean paste (doenjang). The strain CS90 showed antimicrobial activity against food-borne pathogenic bacteria including Salmonella enterica, Salmonella enteritids, Salmonella typhymurium, Bacillus cereus, Listeria ivanovii, Listeria. monocytogenes, Sthaphylococcus aureus, and Sthaphylococcus epidermidis and showed a significant survival rate of 35.7 to $\mathbf{5 7 . 8 \%}$ under the artificial gastric acidic condition (pH 2 to 3). The strain CS90 was classified as Bacillus subtilis based on morphological, physiological, chemotaxonomic features and phylogenetic analysis based on 16S rDNA sequence and designated as B. subtilis CS90. B. subtilis CS90 can be used as a potential probiotics.
\end{abstract}

Key words: probiotics, food-borne pathogenic bacteria, antimicrobial activity, phylogenetic analysis, Bacillus subtilis $\mathrm{CS} 90$

Recently, interest on the probiotics has been increasing [Hong et al., 2005]. Probiotics are generally defined as live microbial feed supplements that can benefit the host by improving its intestinal balance [Fuller, 1989] through immunomodulation, competitive exclusion of gastrointestinal pathogens, and secretion of antimicrobial compounds, which suppress the growth of harmful bacteria [Due Ie et al., 1989; Fuller, 1989]. Although studies have demonstrated a direct probiotics effect of Bacillus spores, preliminary studies with the poultry provided evidence of a competitive exclusion of Escherichia coli $078: \mathrm{K} 80$ by Bacillus subtilis [La Ragion et al., 2001], and a number of studies have demonstrated that harmful bacteria are suppressed by various Bacillus spore formers [Due le et al., 1989; Vaseeharan et al., 2003; Barbosa et al., 2005]. Pinchuk et al. [2001] reported the characterization of an antibiotic produced by the $B$. subtilis strain found in the commercial product Biosporin, known to inhibit the growth of Helicobacter pylori. In addition, a large

*Corresponding author

Phone: 82-61-750-3294; Fax: 82-61-752-8011

E-mail: chokyeman@hanmail.net

Abbreviations: TSA, tryptic soy agar; TSB, tryptic soy broth; MIC, minimal inhibitory concentration; GI, gastrointestinal

doi:10.3839/jabc.2008.044 number of Bacillus products are used as 'novel foods' or as dietary supplements with claims of 'enhancing' the well-being of the user [Hong et al., 2005].

Soybeans and soy-containing foods are excellent and inexpensive sources of dietary proteins, carbohydrates, vitamins, and minerals such as isoflavone, soyasaponin, $\gamma$-aminobutyric acid, trypsin inhibitor, and phytic acid [Anderson et al., 1995; Sung et al., 2004]. In particular, fermented soybean foods, one of a major source of protein of Koreans, such as doenjang (soybean paste), kanjang (soybean source), and cheonggukjang (soybean cook) have served as condiments for thousands of years [Choi et al., 2002]. In the production of Korean traditional fermented soybean foods, Bacillus species notably B. subtilis, B. licheniformis, and B. pumilus are predominantly used [Yoo et al., 1999; Yun et al., 2003; Kim et al., 2004; Paik et al., 2004; Kang et al., 2005; Joo et al., 2007].

In the present study, the isolation of potential probiotics and the classification of the isolate were performed by the morphological, physiological, chemotaxonomic features, and phylogenetic analyses.

\section{Materials and Methods}

Isolation of Bacillus sp. Korean traditional fermented soybean foods, cheonggukjang, deonjang, and kanjang, 
were collected from a local market (Jinju, Korea). Collected samples were diluted with $0.85 \% \mathrm{NaCl}$, and then $0.1 \mathrm{~mL}$ of the diluted suspension was plated on the TSA (Difco, Detroit, MI, USA) plates. After the plates were incubated at $37^{\circ} \mathrm{C}$ for $48 \mathrm{~h}$, a single colony was selected as a pure isolate on each TSA plate. Isolates were stored at $-80^{\circ} \mathrm{C}$ with $20 \%$ sterile glycerol until needed.

Antibacterial activity. Twelve food-borne pathogenic bacteria including Escherichia coli KCTC 1682, Salmonella enterica KCTC 12456, Salmonella enteritids KCTC 12400, Salmonella typhimurium KCTC 1925, Shigella flexineri KCTC 2008, Shigella sonnei KCTC 2518, Bacillus cereus KCTC 1012, Listeria innocula KCTC 3586, L. ivanovii KCTC 3444, Listeria monocytogenes KCTC 3569, Staphylococcus aureus KCTC 1621, and Staphylococcus epidermidis KCTC 3958 were used as test organisms. These test organisms were grown on the TSA plates at $37^{\circ} \mathrm{C}$.

The isolated Bacillus strains were cultured in $250 \mathrm{~mL}$ Erlenmeyer flasks containing $40 \mathrm{~mL}$ of TSB (Difco) at $30^{\circ} \mathrm{C}$ for $48 \mathrm{~h}$ in a gyratory shaking incubator at $150 \mathrm{rpm}$. The cultured cells were removed from the broth by centrifugation at $15,000 \mathrm{rpm}$ for $10 \mathrm{~min}$, and the resultant supernatants were sterilized by filtration through a 0.20 $\mu \mathrm{m}$ non-pyrogenic membrane (Minisart, Sartorius, Goettingen, Germany). Fifty micro-liters of the sterilized supernatant was applied on to the 8-mm sterile paper disk, and the disk was placed on the TSA plate which was spread with a test organism for antibacterial activity assay. After $48 \mathrm{~h}$ of incubation at $37^{\circ} \mathrm{C}$, the antibacterial activity was measured as the diameter of the clear zone formed.

Determination of tolerances of acid, artificial gastric acid, and bile. The method of Hyronimus et al. [2000] was modified to determine the tolerances to acid, artificial gastric acid, and bile acid. For determination of acid tolerance, the isolated Bacillus strains were grown in TSB at $30^{\circ} \mathrm{C}$ for $48 \mathrm{~h}$, and diluted to $10^{6} \mathrm{CFU} \mathrm{mL} \mathrm{mL}^{-1}$ in fresh TSB adjusted to different $\mathrm{pH}$ values $(2,2.5$, and 3$)$ with hydrochloric acid ( $3 \mathrm{M})$. Diluted cells were incubated for 3 and $6 \mathrm{~h}$ at $37^{\circ} \mathrm{C}$. After incubation, the cells were serially diluted in a phosphate buffer $(0.1 \mathrm{M}, \mathrm{pH} 6.2)$ to neutralize the medium acidity, and the viable cells on the TSA plate were counted after $48 \mathrm{~h}$ of incubation at $30^{\circ} \mathrm{C}$. The survival rate was calculated as the percentage of Bacillus $\mathrm{sp}$. colonies grown on the TSA plate compared to the initial bacterial concentration.

For determination of the artificial gastric acid tolerance, an artificial gastric juice was created by adding $1 \%$ pepsin (Sigma, St. Louis, MO, USA) to the TSB at different $\mathrm{pH}$ values $(2,2.5$, and 3$)$. Cells grown in TSB at $30^{\circ} \mathrm{C}$ for 48 $\mathrm{h}$ was diluted to $10^{6} \mathrm{CFU} \mathrm{\textrm {mL } ^ { - 1 }}$ in fresh artificial gastric acids adjusted to different $\mathrm{pH}$ values $(2,2.5$, and 3$)$. Diluted cells were incubated for 3 and $6 \mathrm{~h}$ at $37^{\circ} \mathrm{C}$. After incubation, the cells were serially diluted in phosphate buffer $(0.1 \mathrm{M}, \mathrm{p} \mathrm{H} 6.2)$ to neutralize the medium acidity. The viable cells were then incubated on the TSA plate for $48 \mathrm{~h}$ at $30^{\circ} \mathrm{C}$ and counted. The survival rate was calculated as the percentage of Bacillus sp. colonies grown on the TSA plate compared to the initial bacterial concentration.

For determination of bile tolerance, $15 \mu \mathrm{L}$ of condiment the cells grown in TSB at $30^{\circ} \mathrm{C}$ for $48 \mathrm{~h}$ (equivalent to $10^{6}$

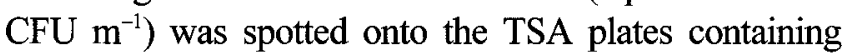
oxgall bile (Sigma) at different concentration $(0.1-1 \% \mathrm{w} / \mathrm{v})$. The plates were incubated at $30^{\circ} \mathrm{C}$ for 5 days. The MIC of the bile for Bacillus strain was determined as the lowest concentration totally inhibiting the cell growth at the spots as judged from visual examination of the spots.

Morphological and physiological characteristics. Cell morphology was examined by light microscopy after Gram staining. Flagellum type was determined by transmission electron microscopy (JEM 1010, JEOL, Tokyo, Japan) using preparations negatively stained with $1 \%$ phosphotungstic acid. Phenotypic characterization was carried out by standard methods using API50CHB kits (bioMérieux, Montalieu Vercieu, France). The methods described by Cowan et al. [1965] were used for the following physiological tests: catalase and oxidase activities, and hydrolyses of gelatin, casein and starch. Growths, in response to various concentrations of $\mathrm{NaCl}$ and temperature range, were determined in TSB as a basal medium.

Chemotaxonomy and DNA base composition. The biomass for cellular fatty acid analysis was prepared from a culture grown on a TSA plate for $24 \mathrm{~h}$ at $37^{\circ} \mathrm{C}$. Fatty acid methyl esters were prepared using the method described in the manual of the MIDI Microbial Identification System. The resultant esters were separated using a gas chromatograph fitted with a phenylmethyl silicone-fused silica capillary column $(25 \mathrm{~m} \times 0.2 \mathrm{~mm}$; Hewlett Packard, Palo Alto, CA, USA). DNA base composition was measured by reversed-phase high pressure liquid chromatography after the DNA was hydrolyzed into nucleosides [Tamaoka et al., 1984].

Sequencing of the 16S rDNA and phylogenetic tree analysis. The $16 \mathrm{~S}$ rDNA of strain CS90 was amplified by PCR. PCR amplification was performed as follows: 30 cycles of denaturation at $90^{\circ} \mathrm{C}$ for $1 \mathrm{~min}$, annealing at $55^{\circ} \mathrm{C}$ for $30 \mathrm{~s}$, and extension at $72^{\circ} \mathrm{C}$ for $1 \mathrm{~min}$. The PCR primers used to amplify $16 \mathrm{~S}$ rDNA fragments were the bacterial-specific, 5'-CGGAGAGTTTGATCCTGG-3' (1BF, forward) and 5'-TACGGCTACCTTGTTACGAC-3' (2BR, reverse) [Cho et al., 2007]. Amplified 16S rDNA fragments were used as the sequencing templates. 
Nucleotide sequences were determined by the dideoxychain termination method using the PRISM Ready Reaction Dye terminator/primer cycle sequencing kit (PerkinElmer, Norwalk, CT, USA). Assembly of the mucleotide sequences was performed with the DNAMAN analysis system (Lynnon Biosoft, Quebec, Canada). All reference sequences were obtained from the National Center for Biotechnology Information (NCBI) and Ribosomal Database Project (RDP) databases. The 16S rDNA similarity values were determined based on the alignments, and the evolutionary distances were calculated. Phylogenetic analysis was performed using neighbor-joining methods [Saito et al., 1987]. Bootstrap analysis was performed using data re-sampled 1,000 times using the DNAMAN analysis system (Lynnon Biosoft). Nucleotide sequence data reported for the $16 \mathrm{~S} \mathrm{rDNA}$ of strain $\mathrm{CS} 90$ are available in the GenBank database under the accession number FJ210720.

\section{Results and Discussion}

Antimicrobial activity against food-borne pathogenic bacteria. A total of 26 samples were collected from soybean fermented foods, cheonggukjang, deonjang, and kanjang. Approximately 150 strains of Bacillus sp. were isolated from these samples. Antibacterial activities of the isolated Bacillus strains against twelve food-borne pathogenic bacteria were tested. Five strains, designated as Bacillus sp. CS9-4, CS45, CS62, CS72, and CS90, showed a broad range of antibacterial activities (Table 1). The Bacillus sp. CS9-4, CS62, and CS90 were isolated from deonjang and Bacillus sp. 45 and Bacillus 72 were obtained from the kanjang. There were many reports that Bacillus sp. has plays important roles in the Korean traditional fermented soybean foods [Yoo et al., 1999; Yun et al., 2003; Kim et al., 2004; Paik et al., 2004; Kang et al., 2005; Joo et al., 2007; Ryu et al., 2007].

All five Bacillus strains showed antibacterial activities against $S$. enteritids, $S$. typhymurium, and $S$. aureus. Bacillus sp. CS9-4 and CS62 showed inhibitory activities against Gram-negative bacteria such as $E$. coli, $S$. enterica, S. enteritids, $S$. typhymurium, $S$. flexineri, and $S$. sonnei, known as the main pathogens causing diarrhea in human [Li et al., 2005; Gast et al., 2006]. The production of an antimicrobial agent is considered to be one of the major functions of the probiotics. Therefore, this function may be one of the principal criteria applied for the screening of potential probiotics strain [Chang et al., 2001; Hong et al., 2005; Guo et al., 2006].

Several Bacillus species secrete antibiotics, some of which are lipopeptide derivatives functioning as a surfaceactive agent [Das et al., 2008]. These lipopeptides including iturin [Maget-Dana et al., 1994], surfactin [Cho et al., 2003], fengycin [Vanittanakom et al., 1986],

Table 1. Antibacterial activity of isolated strains from the different soybean fermented foods when incubated with twelve food-borne pathogenic bacteria

\begin{tabular}{|c|c|c|c|c|c|}
\hline \multirow{3}{*}{$\begin{array}{l}\text { Food-borne } \\
\text { pathogenic microorganisms }\end{array}$} & \multicolumn{5}{|c|}{ Inhibitory zone ${ }^{1)}(\mathrm{mm})$} \\
\hline & \multicolumn{5}{|c|}{ Isolated strain } \\
\hline & $\operatorname{CS9-4}$ & CS45 & CS62 & $\mathrm{CS} 72$ & CS90 \\
\hline \multicolumn{6}{|l|}{ Gram-negative bacteria } \\
\hline E. coli $\mathrm{KCTC}^{2)} 1682$ & 12.4 & -3) & 21.3 & 9.7 & - \\
\hline S. enterica KCTC 12456 & 19.2 & 9.8 & 24.5 & - & 9.6 \\
\hline S. enteritids KCTC 12400 & 28.4 & 13.2 & 29.1 & 24.7 & 12.7 \\
\hline S. typhymurium KCTC 1925 & 27.8 & 22.4 & 28.6 & 25.6 & 13.4 \\
\hline S. flexineri KCTC 2008 & 24.1 & 12.8 & 23.9 & 12.9 & - \\
\hline S. sonnei KCTC 2518 & 26.2 & 14.4 & 27.0 & 25.9 & - \\
\hline \multicolumn{6}{|l|}{ Gram-positive bacteria } \\
\hline B. cereus KCTC 1012 & 30.1 & 25.6 & 29.8 & - & 26.1 \\
\hline L. innocula KCTC 3586 & 14.3 & - & - & - & - \\
\hline L. ivanovii $\mathrm{KCTC} 3444$ & 24.8 & 11.8 & 23.1 & - & 23.9 \\
\hline L. monocytogenes KCTC 3589 & 25.7 & 21.9 & 14.3 & - & 25.6 \\
\hline S. aureus KCTC 1621 & 22.6 & 12.7 & 23.2 & 13.6 & 14.3 \\
\hline S. epidermidis KCTC 3958 & - & 11.6 & 22.7 & 11.7 & 12.8 \\
\hline
\end{tabular}

${ }^{1}$ The antifungal activity was estimated by measuring the diameter of the clear zone (including paper disks, $8 \mathrm{~mm}$ diameter) of growth inhibition.

${ }^{2)}$ KCTC, Korea Collection for Type Culture

${ }^{3)}$, no inhibition 
Table 2. Survival rate of isolated strains from different soybean fermented foods under acidic condition after 3 and $6 \mathrm{~h}$ of incubation ${ }^{1)}$

\begin{tabular}{ccrrr}
\hline \hline \multirow{2}{*}{$\begin{array}{c}\text { Isolated } \\
\text { strain }\end{array}$} & $\begin{array}{c}\text { Incubation } \\
\text { time }(\mathrm{h})\end{array}$ & \multicolumn{3}{c}{ Survival rate (\%) } \\
\cline { 3 - 5 } & & \multicolumn{1}{c}{$\mathrm{pH}$} \\
\hline \multirow{2}{*}{ CS9-4 } & 3 & 5.2 & 11.2 & 14.1 \\
& 6 & 0.3 & 5.2 & 5.2 \\
CS45 & 3 & 11.6 & 25.0 & 23.0 \\
& 6 & 5.0 & 16.6 & 20.0 \\
CS62 & 3 & 16.8 & 25.7 & 29.7 \\
& 6 & 8.9 & 16.8 & 24.8 \\
CS72 & 3 & 16.9 & 27.6 & 30.7 \\
& 6 & 6.1 & 10.0 & 23.4 \\
CS90 & 3 & 42.5 & 55.3 & 59.5 \\
& 6 & 23.4 & 38.3 & 46.8 \\
\hline
\end{tabular}

${ }^{15}$ Each isolated Bacillus sp. was tested in triplicate for its tolerance in acidified TSB.

plipastatin [Tasuge et al., 1996] lichenysin [Yakimov et al., 1995], pumilacidin [Naruse et al., 1990] and di- and tripeptides such as bacilysin [Walker et al., '1970] synthesize non-ribosomally. In particular, $B$. subtilis produces the antimicrobial lipopeptides such as surfactin, fengycin, iturin, bacillomycins, and mycosubtilins [Vater et al., 2002; Kim et al., 2007].

Survival rates of Bacillus sp. under gastrointestinal tract conditions. Survival rates of several Bacillus strains under acidic conditions are shown in Table 2. In general, survival rates of the isolated Bacillus sp. decrease with the lapse of time under acidic condition. One of the tested Bacillus sp., CS90, showed a significantly high survival rate. Survival rates of the strain CS90 were 35.7 (at pH 2),

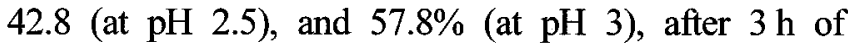
incubation. Other Bacillus sp. such as CS9-4, CS45, CS62, and CS72 showed somewhat lower survival rates.

Survival rates of the isolated Bacillus strains under artificial gastric conditions are shown in Table 3. A slightly lower degree of survival rates were observed under the artificial gastric condition compared with the acidic condition (Table 2). Low survival rates were observed from Bacillus strains CS9-4, CS45, CS62, and CS72: 2.4 to 12.1 after $3 \mathrm{~h}$ and 0 to 1.1 after $6 \mathrm{~h}$ at $\mathrm{pH} 2$; 6.1 to 19.2 after $3 \mathrm{~h}$ and 0 to 2.1 after $6 \mathrm{~h}$ at $\mathrm{pH} 2.5$; and 9.1 to 25.6 after $3 \mathrm{~h}$ and 3.1 to $4.2 \%$ after $6 \mathrm{~h}$ at $\mathrm{pH} 3$, respectively. On the other hand, Bacillus sp. CS90 showed the significantly higher survival rates of 35.7 at $\mathrm{pH} 2.0,42.8$ at $\mathrm{pH} 2.5$, and $57.8 \%$ at $\mathrm{pH} 3.0$ after $3 \mathrm{~h}$. All strains were able to withstand bile concentration higher than $1.0 \%$ (data not shown).

Bacillus probiotics differ in many characteristics from
Table 3. Survival rate of isolated strains from different soybean fermented foods under artificial gastric acidic condition after 3 and 6 h of incubation ${ }^{1)}$

\begin{tabular}{ccccc}
\hline \hline \multirow{2}{*}{$\begin{array}{c}\text { Isolated } \\
\text { strain }\end{array}$} & $\begin{array}{c}\text { Incubation } \\
\text { time (h) }\end{array}$ & \multicolumn{3}{c}{ Survival rate (\%) } \\
\cline { 3 - 5 } & & 2 & 2.5 & 3 \\
\hline \multirow{2}{*}{ CS9-4 } & 3 & 2.4 & 6.1 & 9.1 \\
& 6 & 0 & 0 & 3.1 \\
CS45 & 3 & 8.6 & 14.9 & 17.3 \\
& 6 & 0 & 1.8 & 4.7 \\
CS62 & 3 & 12.1 & 18.1 & 23.6 \\
& 6 & 1.1 & 1.8 & 4.5 \\
CS72 & 3 & 11.8 & 19.2 & 25.6 \\
& 6 & 1.0 & 2.1 & 4.2 \\
CS90 & 3 & 35.7 & 42.8 & 57.8 \\
& 6 & 14.3 & 21.4 & 28.5 \\
\hline
\end{tabular}

${ }^{1)}$ Each isolated Bacillus sp. was tested in triplicate for its tolerance in artificial gastric acidified TSB.

those based on lactic acid bacteria [Chang et al., 2001; Kim, 2005]. Whereas lactobacilli represent a normal resident GI microflora of humans, the saprophytic GI bacteria of Bacillus genera belong only to the transitory GI bacteria. Thus, the use of Bacillus products raised a number of questions, including their safety. Over the past three decades, this genus has expanded to accommodate more than 100 species [Sorokulova et al., 2008]. However, only a few of these species are used as probiotics for human: $B$. subtilis, $B$. licheniformis, $B$. calusii, $B$. coagulans, B. cereus, B. pumilus, Bacillus laterosporus, as well as some invalid species named as $B$. toyo $i$ and $B$. polyfermenticus [Due Ie et al., 2004; Urdaci et al., 2004]. On the contrary, Sorokulova et al. [2008] recently reported that $B$. subtilis strain may be considered as nonpathogenic and safe for human consumption.

Identification of potential probiotic Bacillus sp. CS90. The morphological, biochemical, and physiological characteristics of the strain CS90 were analyzed (Table 4). The cells, incubated for $24 \mathrm{~h}$ at $37^{\circ} \mathrm{C}$, were Grampositive and rod-shaped, measuring 0.6 to $0.8 \times 2$ to $3 \mu \mathrm{m}$. The strain was facultatively anaerobic and grew at 10 to $50^{\circ} \mathrm{C}$ with an optimum growth temperature of 30 to $37^{\circ} \mathrm{C}$. The strain grew in the presence of 0 to $15 \%(\mathrm{w} / \mathrm{v}) \mathrm{NaCl}$ and had catalase and oxidase activities, but no urease activity. Skim milk, gelatin, cellulose, and starch were hydrolyzed by CS90. Reactions for the oxidation and fermentation of carbohydrates as the sole carbon sources are shown in Table 4. The cellular fatty acid profile of strain CS90 revealed the presence of large amounts of saturated and branched fatty acids, and the majority of the fatty acids had the iso- $\mathrm{C}_{15: 0}(25.44 \%)$ and anteiso- $\mathrm{C}_{15: 0}$ 
Table 4. Phenotypic characteristics of Bacillus subtillis CS90

\begin{tabular}{|c|c|c|c|}
\hline Characteristics & Reaction & Characteristics & Reaction \\
\hline Morphology & & Rhamnose & - \\
\hline Shape & Rod & Dulcitol & - \\
\hline Gram stain & + & Inositol & + \\
\hline Cell dimension $(\mu \mathrm{m})$ & 0.6 to $0.8 \times 2$ to 3 & Mannitol & + \\
\hline Flagellation & + & Sorbitol & + \\
\hline Swarming on soft TS agar & + & $\alpha$ methyl-D-mannoside & - \\
\hline Endospore formation & + & $\alpha$ methyl-D-glucoside & + \\
\hline Physiological properties & & $N$ acetyl glucosamine & - \\
\hline Aerobic growth & + & Amygdaline & + \\
\hline Growth at temperature $\left({ }^{\circ} \mathrm{C}\right)$ & 10 to 50 & Arbutine & + \\
\hline Growth in $\mathrm{NaCl}(\%)$ & $<15$ & Esuline & + \\
\hline Biochemical characteristics & & Salicine & + \\
\hline Oxidase activity & + & Cellobiose & + \\
\hline Catalase activity & + & Maltose & + \\
\hline Urease activity & - & Lactose & - \\
\hline Hydrolysis of & & Melibiose & + \\
\hline Skim milk & + & Saccharose & + \\
\hline Casein & - & Trehalose & + \\
\hline Gelatin & + & Inuline & - \\
\hline Cellulose & + & Melezit ose & - \\
\hline Starch & + & D-raffinose & + \\
\hline Carbohyrates & & Amidon & + \\
\hline Glycerol & + & Glycogen & + \\
\hline Ertythritol & - & Xylitol & - \\
\hline D-arabinose & - & $\beta$ gentiobiose & + \\
\hline L-arabinose & + & D-turanose & - \\
\hline Ribose & + & D-lyxose & - \\
\hline D-xylose & + & D-tagatose & - \\
\hline L-xylose & - & D-fucose & - \\
\hline Adonitol & - & L-fucose & - \\
\hline$\beta$ methyl-xyloside & - & D-arabitol & - \\
\hline Galactose & - & L-arabitol & - \\
\hline D-glucose & + & Gluconate & - \\
\hline D-fructose & + & 2 ceto-gluconate & - \\
\hline D-mannose & + & 2 ceto-gluconate & - \\
\hline L-sorbose & - & DNA $\mathrm{G}+\mathrm{C}$ content $(\mathrm{mol} \%)$ & 53.5 \\
\hline
\end{tabular}

${ }^{11}$ Symbol: + , positive reaction; -, negative reaction.

(39.84\%) (data not shown). The $\mathrm{G}+\mathrm{C}$ content of the DNA was $53.5 \mathrm{~mol} \%$. Morphological, biochemical, and physiological analyses clearly demonstrated that strain CS90 is a member of the genus Bacillus. The chemotaxonomic data, i.e. $\mathrm{G}+\mathrm{C}$ content of DNA and the anteiso- $\mathrm{C}_{15: 0}$ as the major cellular fatty acid also fall within the ranges found in the Bacillus species. In addition, results of the physiological properties indicated strain CS90 differs from the other species of Bacillus in the carbohydrate utilization pattern. Not enough properties were examined in this study to compare the bacterium in more detail with the description available in the Bergey's Manual.

A complete 16S rDNA sequence of strain CS90 $(1,517$ bp; accession number; FJ210720) was determined. A phylogenetic tree constructed using the sequence data showed that strain CS90 grouped within the evolutionary radiation, encompassing the genus Bacillus and occupying a distinct phylogenetic position within this genus. The level of 16S rRNA similarity between strain GS01 and the Bacillus species ranged from 91.4 to $99.6 \%$. The highest 16S rDNA sequence similarity (99.7\%) was 


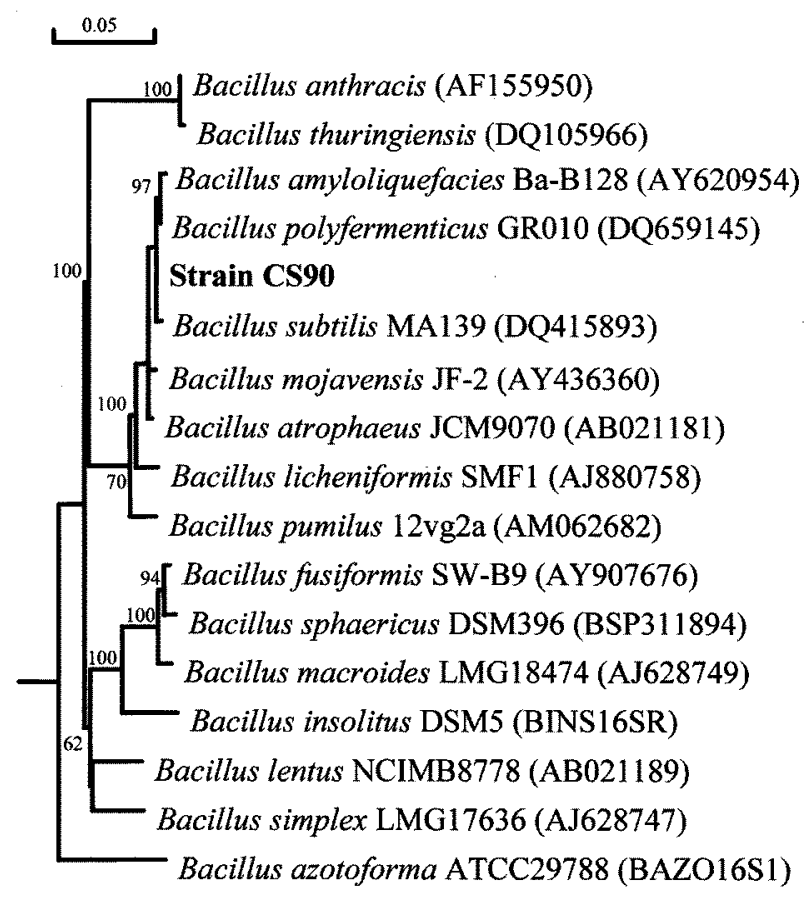

Fig. 1. Phylogenetic relationships of strain CS90 and other closely related Bacillus sp. based on 16S rDNA. Number above each node us the confidence level (\%) generated from 1,000 bootrap trees. The scale bar is in fixed nucleotide substitutions per sequences position.

observed between strain CS90 and B. subtillis MA139 (Fig. 1). Broad-range amplification and sequencing of 16S rDNA templates are useful for the characterization of many species. There are several advantages to using the ribosomal gene sequences for taxonomic purposes. DNA is more easily isolated and manipulated than RNA and can be readily sequenced, thus making it a more appropriate choice for routine analysis. Regions of the nucleotide conservation allow the selection of a broadrange or universal oligonucleotide primers for PCR amplification of virtually all prokaryotic organisms, assuming that they contain similar nucleotide sequences at the corresponding primer-binding sites [Cho et al., 2007]. The present phylogenetic study clearly established that strain CS90 is closely related to B. subtillis. To the best of our knowledge, this is the first report on the isolation of a potential probiotic Bacillus subtilis from doenjang.

In conclusion, the present study identified the probiotic activity of $B$. subtilis CS90 against the food-borne pathogenic bacteria such as $S$. enteric, $S$. enteritids, $S$. typhymurium, B. cereus, L. ivanovii, L. monocytogenes, $S$. aureus, and $S$. epidermidis. B. subtilis CS90 can be used as a probiont against the food-borne pathogenic bacteria.

\section{Acknowledgments}

This work was supported by a grant (No. 08-C2-15002) from the Academic-industrial Cooperative Research Program of the Small \& Medium Business Administration (SMBA), Republic of Korea. This work was supported by 2008 Post Doctoral Course Program of Sunchon National University, Republic of Korea.

\section{References}

Anderson, R.L., Wolf, W.J (1995) Compositional changes in trypsin inhibitors, phytic acid, saponins and isoflavones related to soybean processing. $J$ Nutr $125,581 \mathrm{~S}-588 \mathrm{~S}$.

Barbosa TM, Serra CR, La Ragione RM, Woodward MJ, and Henriques AO (2005) Screening for Bacillus isolates in the broiler gastrointestinal tract. Appl Environ Microbiol 71, 968-978.

Chang YH, Kim JK, Kim HJ, Kim WY, Kim YB, and Park YH (2001) Selection of a potential probiotic Lactobacillus strain and subsequent in vivo studies. Antonie van Leeuwenhoek 80, 193-199.

Cho KM and Seo WT (2007) Bacterial diversity in a Korean traditional soybean fermented foods (doenjang and ganjang) by 16S rRNA gene sequence analysis. Food Sci Biotechnol 16, 320-324.

Cho SJ, Hong SY, Kim JY, Park SR, Kim MK, Lim WJ, Shin EC, Kim EJ, Cho YU, and Yun HD (2003) Endophytic Bacillus sp. CY22 from a balloon flower (Platycodon grandiflorum) produces surfactin isoforms. $J$ Microbiol Biotechnol 13, 859-865.

Choi YS, Kim JH, and Yoon DH (2002) Effects of soy extract and sex on serum and liver lipid levels of the rat. Food Sci Biotechnol 11, 10-13.

Cowan ST and Steel KJ (1965) In Mamual for the Identification of Medical Bacteria Cambridge University Press, London, UK.

Das P, Mukherjee S, and Sen R (2008) Antimicrobial potential of a lipopeptide biosurfactant derived from a marine Bacillus circulans. J Appl Microbiol 104, 1675-84.

Duc Ie H, Hong HA, Barbosa TM, Henriques AO, and Cutting SM (2004) Characterization of Bacillus probiotics available for human use. Appl Environ Microbiol 70, 2161-2171.

Fuller R (1989) Probiotics in man and animals. $J$ Appl Bacteriol 66, 365-378.

Gast RK, Holt PS, and Guraya R (2006) Effect of refrigeration on in vitro penetration of Salmonella enteritidis through the egg yolk membrane. J Food Prot 69, 14261429.

Guo X, Li D, Lu W, Piao X, and Chen X (2006) Screening of Bacillus strains as potential probiotics and subsequent confirmation of the in vivo effectiveness of Bacillus subtilis MA139 in pigs. Antonine van Leeuwenhoek 90, 
$139-146$.

Hong HA, Due Ie $\mathrm{H}$, and Cutting SM (2005) The use of bacterial spore formers as probiotics. FEMS Microbiol Rev 29, 813-835.

Hyronimus B, Le Marrec C, Hadj Sassi A, and Deschamps A (2000) Acid and bile tolerance of spore-forming lactic acid bacteria. Int $J$ Food Microbiol 61, 193-197.

Joo MH, Hur SH, Han YS, and Kim JY (2007) Isolation, identification, and characterization of Bacillus strains from the traditional Korean Soybean-fermented food, chungkookjang. I Appl Biol Chem 50, 202-210.

Kang SE, Rhee JH, Park C, Sung MH, and Lee IH (2005) Distribution of poly- $\gamma$-glutamate $(\gamma$-PGA) producers in Korean fermented foods, cheongkukjang, doenjang, and kochujang. Food Sci Biotechnol 14, 364-372.

Kim DH, Song HP, Kim KY, Kim JO, and Byun MW (2004) A correlation between fibrinolytic activity and microflora in Korean fermented soybean products. $J$ Korean Soc Food Sci Nutr 33, 41-46.

Kim SA, Lee YG, Choi YL, Hwang CW, Jeong YK, and Joo WH (2007) Physiological characteristics of biosurfactant-producing Bacillus subtilis TMB 3101. J Korean Soc Appl Biol Chem 50, 12-17.

Kim SJ (2005) Potential probiotic of lactic acid bacteria isolated from kimchi. Food Sci Biotechnol 14, 503-508.

La Ragione RM, Casula G, Cutting SM, and Woodward SM (2001) Bacillus subtilis spores competitively exclude Escherichia coli 070:K80 in poultry. Vet Microbiol 79, 133-142.

Li Y, Zhuang S, and Mustapha A (2005) Application of a multiplex PCR for the simultaneous detection of Escherichia coli O157:H7, Salmonella and Shigella in raw and ready-to-eat meat products. Meat $S_{c i} \mathbf{7 1}, 402-406$.

Maget-Dana R and Peypoux F (1994) Iturins, a special class of poreforming lipopeptides: Biological and physicochemical properties. Toxicology 87, 151-174.

Naruse N, Tenmyo O, Kobaru S, Kamei H, Miyak T, Konishi M, and Oki T (1990) Pumilacidin, a complex of new antiviral antibiotics - production, isolation, chemical properties, structure and biological activity. $J$ Antibiot 43, 267-280.

Paik HD, Lee SK, Heo S, Kim SY, Lee HH, and Kwon TJ (2004) Purification and characterization of the fibrinolytic enzyme produced by Bacillus subtilis KCK-7 from chungkookjang. J Microbiol Biotechnol 14, 829-835.

Pinchuk IV, Bressollier P, Verneuil B, Fenet B, Sorokulova IB, Megraud F, and Urdaci MC (2001) In vitro antiHelicobacter pylori activity of the probiotic strain Bacillus subtilis 3 is due to secretion of antibiotics. Antimicrob Agents Chemother 45, 3156-3161.

Ryu HS, Shon MY, Cho SJ, Park SK, and Lee SW (2007) Characterization of antibacterial substance - Producing Bacillus subtilis isolated from traditional Doenjang. $J$ Korean Soc Appl Biol Chem 50, 87-94.
Saito $\mathrm{N}$ and Nei M (1987) The neighbor-joining method: A new method for reconstructing phylogenetic trees. Mol Biol Evol 4, 406-425.

Sorokulova IB, Pinchuk IV, Denayrolles M, Osipova IG, Huang JM, Cutting SM, and Urdaci MC (2008) The safety of two Bacillus probiotic strains for human use. Dig Dis Sci 53, 954-963.

Sung JH, Choi SJ, Lee SW, Park KH, and Moon TW (2004) Isoflavones found in Korean soybean paste as 3hydroxy-3-methylglutaryl coenzyme a reductase inhibitors. Biosci Biotechnol Biochem 68, 1051-1058.

Tamaoka J and Komagata K (1984) Determination of DNA base composition by reversed-phase high-performance liquid chromatography, FEMS Microbiol Lett 25, 125128.

Tsuge K, Ano T, and Shoda M (1996) Isolation of a gene essential for biosynthesis of the lipopeptide antibiotics plipastatin B1 and surfactin in Bacillus subtilis YB8. Arch Microbiol 165, 243-251.

Urdaci MC and Pinchuk I (2004) Antimicrobial activity of Bacillus probiotics. In Bacterial spore formers: probiotics and emerging applications. Ricca E, Henriques AO, Cutting SM (eds) pp. 93-106, Horizon Bioscience, Norfolk, UK.

Vanittanakom N, Loeffler W, Koch U, and Jung G (1986) Fengycin - a novel antifungal lipopeptide antibiotic produced by Bacillus subtilis F-29-3. $J$ Antibiot 39, 888901.

Vaseeharan B and Ramasamy P (2003) Control of pathogenic Vibrio spp. by Bacillus subtilis BT23, a possible probiotic treatment for black tiger shrimp Penaeus monodon. Lett Appl Microbiol 36, 83-87.

Vater J, Kablitz B, Wilde C, Franke P, Mehta N, and Cameotra SS (2002) Matrix-assisted laser desorption ionization-time of flight mass spectrometry of lipopeptide biosurfactants in whole cells and culture filtrates of Bacillus subtilis C-1 isolated from petroleum sludge. Appl Environ Microbiol 68, 6210-6219.

Walker JE and Abraham EP (1970) The structure of bacilysin and other products of Bacillus subtilis. Biochem $J$ 118, $563-570$.

Yakimov MM, Timmis KN, Wray V, and Fredrickson HL (1995) Characterization of a new lipopeptide surfactant produced by thermotolerant and halotolerant subsurface Bacillus licheniformis. Appl Environ Microbiol 61, 17061713.

Yoo SK, Cho WH., Kang SM, and Lee SH (1999) Isolation and identification of microorganisms in Korean traditional soybean paste and soybean sauce. Korean $J$ Appl Microbiol Biotechnol 27, 113-117.

Yun GH, Lee ET, and Kim SD (2003) Purification and characterization of a fibrinolytic enzyme produced from Bacillus amyloliquefaciens K42 isolated from Korean soy sauce. Korean J Microbiol Biotechnol 31, 284-291. 